\title{
Was ist Ruhm, der Größe Glück? - Franz Grillparzer's Response to the Value of Fame and Fortune in Der Traum ein Leben
}

\section{Edward McDonald}

Most of the dramatic action is already over by the time Rustan ventures to answer the weighty question that the Dream-King of Samarkand had posed to him, and finding the solution to this problem of "Was ist Ruhm, der Größe Glück?"(1810) ${ }^{1}$ is of major concern to Grillparzer in Der Traum ein Leben. Rustan finally gives his personal opinion on the issue, but only in the aftermath of his frightful dream:

Eines nur ist Glück hienieden,

Eins, des Innern stiller Frieden

Und die schuldbefreite Brust.

Und die Größe ist gefährlich,

Und der Ruhm ein leeres Spiel.

Was er gibt, sind nichtge Schatten,

Was er nimmt, es ist so viel" ( 2650-2656).

Since Grillparzer considered the topic to be most serious, the obvious question that arises is why he decided to superimpose a fairy-tale-like or seemingly happy ending on to his drama by allowing his protagonist, a consummate egoist who has been driven by unrealistic desires from the play's outset, to abruptly and uncharacteristically denounce his wrongful ambition and megalomania. How are we to judge Grillparzer's bewildering last minute departure from portraying his character as psychologically rent by a destructive dualism. One is given the impression that Rustan has been suddenly infused with remarkable grace, since it appears that the ultimate answer to the dramatist's central inquiry into the source of spiritual fulfillment is provided by none other than the troubled "hero" himself. By suspending its belief in the information provided by the previous dramatic action, an audience could assume that Rustan will now progress in some enlightened fashion until he has attained eudæmonia. Yet by itself, Rustan's neat formula for happiness is insufficient proof that he has undergone a positive spiritual metamorphosis as a result of his traumatic, nocturnal experience. In all probability, Rustan is but one more addition to the

1. Quotations have been taken from Franz Grillparzer, Sämtliche Werke, Ausgewählte Briefe, Gespräche, Berichte, edited by Peter Frank and Karl Pörnbacher, 4 vols, Munich 1960-65. 
seriously flawed characters in Grillparzer's store of Triebmenschen. In pursuit of illicit goals, the poet's overly-ambitious protagonists lose sight of how to come to a lasting sense of spiritual well-being through morally correct and legitimate forms of living. Nevertheless, in Der Traum ein Leben Grillparzer does bring to the stage an unequivocal moral valuation of that life which is free from all forms of duplicity, but despite Rustan's closing claims in support of his positive change of heart, it is highly unlikely that Rustan learns to accept the actual message of his dream: "know thyself".

This old, familiar theme that all human beings must guard against succumbing to appearances that hinder self-knowledge is already adumbrated at the close of Act $I$ in the dervish's song. Thereupon, in different guises this same warning is repeatedly rejected by the unrealistic dreamer Rustan, for he cannot renounce his pretentious ambitions. Rustan desires fame, fortune, and the attainment of a grandiosity for which his natural abilities prove insufficient. One could conjecture that the ambiguous finale of this play which is subtitled a "dramatisches Märchen" might have been precipitated by the playwright's own desire to find some momentary relief from a pessimistic conviction that his appeal for "Entsagung" would be ignored by megalomaniacs throughout history. Grillparzer was convinced that the failure of fame-seekers such as Rustan to heed his admonition by renouncing their illicit desires would result not only in personal destruction but also in broad social chaos. The poet lets Rustan carry out his malevolent deeds in the safe haven of a dream from which he awakens unscathed, whereas no second chance for redemption is given to his other wrongfully ambitious characters who move about in the real world. Once attained, the coveted object of their quest becomes their nemesis. These Tatmenschen who are prone to irrational action, men such as Jason and König Ottokar, understand such a plea for moderation when it is much too late. Both Jason and König Ottokar came into dramatic being shortly after Grillparzer had abandoned Der Traum ein Leben as a fragment in 1817-18, and their fate is unequivocally dire, unlike the ambiguous destiny that awaits Rustan as the dream-play concludes. However, despite its classification as a "dramatisches Märchen", Grillparzer's dream-play offers a great deal of evidence which indicates that Rustan too is doomed to a life of continued disenchantment, and, thus, the seeming fairy-talelike redemption that he has undergone is questionable.

Rustan attempts to impress people by chicanery throughout the play. He wants them to acknowledge him as a man of noble stature, and in so doing he is prepared to efface his true identity. The dream is a keen revelation of the extent of Rustan's personal failure, and the awakened man's praise of the simple life is a means of displacement by which he seeks to disguise the fundamental truth of his being that his conscious mind finds impossible to accept. In the closing scenes of the drama, Rustan's late subscription to the tenets of a Biedermeier-like, 
conservative viewpoint and his purported love of idyllic domesticity, are prompted by a psychological mechanism that would readily continue to mask his inability to legitimately gain the greatness he covets. Raging passion, the source of Rustan's unrealistic aspirations, is not dispelled by his fearful nightmare, and despite the lack of solemnity accorded the play by its subtitle, Rustan cannot be viewed as being akin to a slumbering fairy-tale prince; upon awakening, no indemnification from mental torment is guaranteed him as a result of his final pronouncement that links happiness to a life of quiet simplicity. Time and again, Rustan has shown himself to be an uncaring egoist whose overriding concern is with personal recognition. His far-fetched dreams of grandeur coincide with the similarly excessive, immoral aspirations of other ambitious "heroes", but with the important difference that Grillparzer has the latter sowing the seeds of their destruction in the real world. Thus, the matter of his ultimate fate remains unresolved, although judging from antecedents within the play, especially his consistently base behaviour, 2 the chance that Rustan's mentality would ever let him come to enjoy spiritual peace is improbable. In effect, the ostensibly positive or happy conclusion to Grillparzer's play is suspect, and we are left instead with an open ending. Although appearances on stage belie the notion that the error of Rustan's ways has not been corrected or that his behaviour ultimately could be responsible for his unhappy demise, for he is heard asserting authoritatively that one thing and one thing alone brings "Glück hienieden, / Eins, des Innern stiller Frieden / Und die schuldbefreite Brust / Und die Größe ist gefährlich [...]", nevertheless, Rustan's role as the hero-spokesman designated by Grillparzer to impart his message on how best to reach life's highest ideal, spiritual contentment, is open to debate. One may be skeptical regarding Rustan's simplistic formula for universal serendipity. For Grillparzer, it scarcely would serve as credible means for solving the problem, especially in light of the fact that Rustan advocates his way as the sole means for everyone to attain happiness, namely through a renunciation of all personal ambition and an espousal of humble cottage-life. The problem is exacerbated when we take into consideration how the poet's Weltanschauung was grounded in the assumption that the

2. Shortly after the play opens, Mirza mourns her loss of the past when Rustan had helped her with the household chores while telling her fairy-tales. She characterizes him as having been "sanft", "fromm", "mild", and "gut" (109); yet whenever it comes to describing Rustan, the love-sick Mirza always speaks her heart. Mirza longs for a return to the pristine innocence of childhood when ambitious passions had not yet taken hold of Rustan. Regardless, throughout the course of the drama, we never witness Rustan exhibiting the positive traits of gentleness, piety and goodness. Therefore, one could deduce that in lieu of Mirza's emotional statements, a more effective formula on which to base judgment of Rustan's behaviour might be the so-called "razor" of the philosopher William of Occam, namely "as a being is, so a being acts; as a being acts, so a being is". 
attainment of "happiness" - or, more precisely, the avoidance of despair - is linked to an individual's capacity to enjoy a quiet concord of the soul - "des Innern stiller Frieden / und die schuldbefreite Brust" - through ethical behaviour. For Grillparzer, it is not "greatness" in and of itself that human beings must forswear before inner spiritual peace might prevail, but rather unrealistic ambition that only leads to corruption; and from beginning to end, Rustan never shows any indication of wanting to renounce his illicit desires. When finally aroused from the dream, his desire to transcend his limitations continues to seethe within him, notwithstanding the momentary arrest of his reckless urges effected only by their repression.

Grillparzer distrusted the human will as a generally effective guide toward the goal of self-fulfillment, for overly-ambitious and emotionally-driven Tatmenschen who pursue their grand designs as though engaged in a game of little consequence had disquieted him. ${ }^{3}$ Grillparzer considered the obsessions of such adventurers to be mere Schatten devoid of true substance and their irrational actions to be a menace to the welfare of innocent people with whom they came into contact. Thus, the poet advocated a need for all members of society to curb the will's desire for gratification; in lieu of its demanding appetite, Grillparzer favoured a conscious affirmation of the personal and social need for selflimitation. ${ }^{4}$ The purportedly melancholy doctrine of renunciation that he preached as being vital for the avoidance of greater discomfort was in fact the conscious rejection of Schatten, illusory goals that might lead a person away from a righteous pursuit of truth. Grillparzer's recurring admonition to harness the insatiable will by consciously renouncing illicit desires, and calling for resignation to a life of moderation, is by no means a condemnation of all ambition and related action per se. Nowhere does he express opposition to licit ambition nor to greatness and the distinction that came with it, so long as such

3. Grillparzer was ambivalent about his own poetic activity and was unable to recognize that embedded in every good writer's heart there is a sliver of ice that allows the poet to transmute his experiences - especially those with friends -into wise monuments. Therefore, at certain times he was able to associate his work with duty and moral action, whereas at others with only a callous exploitation of friends as "Stoff zu Taten". His occasional loss of Sammlung prevented a sustained concentration, and his inability to remain steadily composed and work as a creative and productive human being led him to conclude that irrationally motivated Tatmenschen were the bane of world harmony. Consequently, while demythologizing his impulsive heroes, Grillparzer simultaneously visited poetic justice upon himself. After the defeat of Napoleon and the ensuing Congress of Vienna in 1815, his pleas favoured a rather conservative (Biedermeier) restraint and discipline that was alien to the behaviour of the unbridled, self-indulgent "man of action". 
fame is honestly achieved..$^{5}$ Although realizing that it was necessary to keep destructive passions in check for the sake of social justice, Grillparzer still lauded as truly great those individuals who could live within their bounds, while quietly bearing the burdens of life. He believed that their collective efforts tended to bond them together and elevated the entire human race. The way in which Grillparzer's honest, psychologically integrated characters comport themselves stands in sharp contrast with the behaviour of the solipsists who relentlessly pursue selfish interests that wreak social and self-destruction. Consequently, the true greatness of the noble Rudolf stands in telltale juxtaposition to the stature of the tyrannical Ottokar; similarly, the just King of Samarkand is the counterpart of the devious Rustan who lacks the innate capability of legitimately gaining an exalted status. ${ }^{6}$

4. Grillparzer's expression of this view in Das Goldene Vließ already seems to bring out the pessimistic overtones of Schopenhauer's philosophy, for here the poet implies that suffering can only cease once and for all by an absolute negation of the will. Before Medea informs Jason that his eye will never again behold her, she expresses her ultimate regret that is fundamental to understanding what motivated her to commit infanticide. She claims that she wants her children to be free of the painful suffering wrought by existence: "Nicht traur ich, daß die Kinder nicht mehr sind. / Ich traure, daß sie waren und daß wir sind" (2324-2325). Nevertheless, a totally nihilistic renunciation of human existence did not fit into Grillparzer's own psychological schemata. Despite the disappointment that he suffered, especially at the hands of his critics, Grillparzer continued to write plays that validated unvarnished truth and moral living.

5. Like most other Austrian intellectuals who were active during the historical period of Vormärz, the irritating, petty restrictions of Metternich's government censorship vexed Grillparzer, yet he did not promulgate an apolitical doctrine which tended to regard all earthly ambition as pure vanity. Although at times the troubled Grillparzer considered himself guilty of using people as Stoff for his dramatic deeds, he also recognized how many good, conscientious and just intellectuals suffered because of government censorship. His own passive and pessimistic personality, his relationships with women, and the very problematic relationship that he experienced as a writer working within a suffocating system of harsh censorship carried out by Metternich's reactionary regime - which looked askance at Rustan's desire to be frei, or winced when the King of Samarkand was accused by the people of the crime of murder - served only to intensify Grillparzer's ambiguous outlook. However, his personal problems and frustration caused by trying to write guilelessly within the strict confines of government censorship never led him to condemn the aspiration of human beings to strive for genuine perfection.

6. It is not by mere chance that Grillparzer contrasts Rustan's ambition with the situation(s) of the Actual-King of the play's outer frame and of the Dream-King of Samarkand. In the early part of the outer frame of the play, we are told that this King had risen from humble origins similar to Rustan's: "Jener Fürst von 
In seeking to realize their unbounded ambitions, the egotistical "heroes" of Grillparzer's dramas resort to exploitation, treachery, and tyranny.

In Der Traum ein Leben, Grillparzer offers no panacea for happiness in his hero's pseudo-enlightened response to the King of Samarkand's question. Instead, the poet mirrors his personal Weltanschauung in the framework of values embodied within the dervish's song that concludes the first act of the play. Just prior to entering into the dream-world, on the very last night before forsaking life in the "Hütte" that he finds so constraining, Rustan hears strains of music coming from the dervish's harp. As he slips into slumber, Rustan is impelled to echo the words of the familiar song. The text communicates the message that a life spent in pursuit of illusory goals is doomed to become a poor ghost of itself:

Schatten sind des Lebens Güter,

Schatten seiner Freuden Schar,

Schatten Worte, Wünsche, Taten;

Die Gedanken nur sind wahr.

Und die Liebe, die du fühlest,

Und das Gute, das du tust [...] (628-633)

Structurally, the song is a composite of opposites; its contextual elements contrast illicit ambition - clearly Rustan's - with a moral existence where life is filled with substance, love, and sharing. In effect, while the dervish's song is meant to criticize the vanity of Rustan's desires by juxtaposing negative with positive values, it also directs us to a meaningful way of life. The song is a condemnation of all Triebmenschen who like Rustan are driven by a temperament that is inclined to posit fanciful Trugbilder or phantoms over substance and reality; and already at this early stage of the dramatic action, we witness Rustan repressing what his inner voices will intone throughout the drama. He is contemptuous of the song's Wahrheitscredo, of the plea for genuine

Samarkand, [...] War, wie ihr, des Dorfes Sohn, / Jetzt von Macht und Glanz umgüldet" (292-295). However, the Samarkandian King's rise to his position of greatness had taken place within the parameters of acceptable moral behaviour. It is at this time that Zanga equates Rustan with a man born to wear the royal purple, yet the only way that Rustan can experience kingship is within the recesses of his wild imagination. Once he enters the dream-world, he aspires to a royal throne for which he is totally unsuited, and so he attempts to reach his goal through duplicity and murder. We note too that fame and fortune had never endangered the just Dream-King of Samarkand's moral principles, such as is the case with the usurper Rustan. Worldly greatness had never proved to be morally corrupting, no insubstantial illusion nor "leeres Spiel" for either the Actual- or Dream-King, for they possessed the inherent capability to rise to the level of true greatness. We note how Grillparzer makes the dream-monarch fallible, yet endows him with the wisdom to use his power sensibly in the service of his subjects. 
existence contained in the ancient summons, "know thyself" :

Possen! Possen! Andere Bilder

Werden hier im Innern wach.

er sinkt zurück. Die Harfentöne währen fort

König! Zanga! Waffen! Waffen! (636-638)

Zanga is accorded a servant's role on the level of consciousness that constitutes the outer frame of Grillparzer's dream-play, but in the dream he symbolizes a progressively irrational force emerging from Rustan's subconscious, an influential shadow-self who projects the dreamer's latent aspirations and distorted, unrelenting will-to-power. In this regard, Rustan's fairy-tale-like dream of omnipotence in the grand realm of Samarkand manifests his unrealistic wishes. He the cottage-dweller yearns to transcend not only his lowly station in life but also his finite potential for grand design, and refuses to accept his own limitations. The song's call for self-cognition is anathema to Rustan, and the ensuing dream exposes his bent to self-deception. The dervish's song does not mention happiness as life's primary goal, as is the case in the awakened dreamer's declaration that "Eines nur ist Glück hienieden [...]" Its essential concern is instead with positive versus negative living. As Rustan begins to gain power in the dream, he esteems the joys that he experiences as though they were durable goods. To the beguiled dreamer, the happiness of which he speaks as being life's sine qua non is no more than an added possession that he must acquire quickly for himself, yet the valuation of life presented by Grillparzer's mouthpiece, the dervish, is much broader in scope: genuine meaning in life transcends a focus on selfish considerations.

The text of the song contains no general disapproval of normal ambition, yet it does indicate that the mode of living to which Rustan subscribes is precisely what is awry in his life. Limited by his potential to get what he wants legitimately, Rustan advances himself by any means at his disposal, whether ethical or not. He becomes a counterfeit person by opting for a life in which the end for which he dreams is pursued by unrealistic means. For Grillparzer, a "genuine" or "authentic" modality of being can encompass many life-styles, yet he makes it clear that the humble life of Massud and Mirza, which Rustan rejects as humdrum, is ironically the only one to which he might be suited. By being dishonest to himself, Rustan loses himself. ${ }^{7}$ Therefore, through its juxtaposition

7. Erich Hock is correct in his assessment that the greatest loss incurred by Rustan in his ambitious pursuit of the vanities of life denounced in the dervish's song is the very truth of his being: "Was er so bei allen äußeren Gewinnen verliert, 'es ist soviel', nämlich alles Echte in ihm. So wird er zum Betrüger, Mörder, Rebellen und gewalttätigen Tyrannen." Erich Hock, "Grillparzers Drama Der Traum ein Leben", Zeitschrift für Deutschkunde, 54, 2. Heft (1940) p. 54. 
of the realm of shadowy or insubstantial appearances with the real and the quintessential in life, the song insinuates that Rustan must rid himself of negative values and replace them with universally positive ones: Worte, empty words are placed in diametrical opposition to sincere thoughts; Wünsche, reflective of Rustan's egotistical desires, are counter to authentic feelings of Liebe and a life of sharing; and wrongfully ambitious deeds are the antithesis of das Gute, namely acts of genuine goodness that only an individual who is not self-centred is capable of performing. Yet, his nightmarish encounter with a potential self who pushes him to the brink of psychic destruction fails to cure Rustan of his old, unrealistic desires; instead he represses them. He does not learn that happiness stems from genuine, moral living and remains transfixed within his flawed existence. Rustan never comprehends the message that happiness is not the primary consideration of life, but a byproduct of moral, positive, and non-spurious or truthful living.

In Der Traum ein Leben Grillparzer deals with the role that personality plays in determining a person's ability to achieve spiritual contentment, a controversial issue to which he had already given symbolic form in 1816 in Die Ahnfrau, just one year before beginning his dream play. ${ }^{8}$ Der Traum ein Leben had a long history. ${ }^{9}$ Although he started to write this play in 1817 , shortly after he had completed Sappho, Grillparzer then stopped working on it when he turned his attention to König Ottokars Glück und Ende. ${ }^{10}$ Rustan's spirit relates more to

8. Already in Die Ahnfrau Grillparzer had portrayed fate as an inner, psychic force that prevents the protagonist Jaromir from acting reasonably while limiting his freedom of choice. For a treatment of this notion, see my article, "Die Ahnfrau: Franz Grillparzers Metapher des schicksalhaften Lebens", Maske und Kothurn 18 (1972) pp. 3-22. In the aftermath of Die Ahnfrau Grillparzer managed to liberate himself somewhat from critical accusations that he consciously sought to portray fate or necessity as an inexorable power that operated blindly and capriciously outside of human behaviour. Gradually it became apparent that Grillparzer endeavoured to delineate how an irrational impulse constitutes the driving force in the determination of an individual's fate. Thus, Rustan's Naturnotwendigkeit is his uncontrollable will-to-power.

9. Der Traum ein Leben belongs to some very early dramatic plans that Grillparzer intended to carry out. Grillparzer wrote the first act between September 21 and November 6,1817, the year following the completion of Die Ahnfrau and just immediately after he had completed Sappho. Act I was published in 1820, but the entire drama was not finished until 1832, staged in October 1834, and finally printed in 1840. For a more detailed account of the literary historical facts pertaining to the play see Helmut Prang, Grillparzer. Der Traum, ein Leben. Frankfurt am Main (undated), p. 7-17.

10. Grillparzer's reasons for suddenly discontinuing his work on Der Traum ein Leben were varied. On May 5, 1821 Napoleon Bonaparte had died. Fleeting fame, fortune, and the sudden demise of this French sovereign were on Grillparzer's mind 
that of the ill-fated Bohemian king than that of the poetess, for whereas Sappho's passion stems from her desire for a simple life with Phaon, Ottokar is motivated by overweening pride (hubris); similarly, Rustan is driven by blinding ambition to rise above his station and natural limitations. The psychological change which Rustan seems to undergo toward the conclusion of Der Traum ein Leben might seem to be just as radical as the one that causes Sappho to reaffirm her existential position that she had tried to deny out of her love for Phaon. Yet although it appears that Rustan has reconciled himself with his lot, he is incapable of realizing as Sappho did that happiness cannot be gained by trying to become something one can never be. The respective kingdoms of Rustan's and Sappho's existential longings are counterparts. Sappho is torn between devotion to her creative impulses and fulfillment in love. Although she yearns for the joys of the commonplace - "Ich sehe das Land herüberwinken / Mein Aug' erreicht es, aber nicht mein Fuß" (397) - she finally recognizes the futility of her aspirations and renounces her claim. If Sappho's tragedy is linked to her inability to be content with her ordained fate, which is to serve and inspire mankind in her role as seer, she nevertheless reconciles herself to her divine destiny by accepting her exalted status and the truth of her being. Rustan on the other hand never consciously acknowledges his limitations nor truly renounces his desire to transcend his lowly station in life. When he awakens, his troubled heart senses that rapture and exaltation are incompatible with a life of moderation in a humble cottage. Repression is the only possible means for coping with the thought that he must carry on in a life that he finds odious. Consequently, he quickly fixes on another fictitious notion, namely that in and of itself "die Größe ist gefährlich, / Und der Ruhm ein leeres Spiel". He must try to convince himself that striving for fame and greatness precludes happiness for anyone at all.

Grillparzer depicts Rustan as an egomaniac with unlimited aspirations, who at the same time lacks the leadership qualities and the fortitude of the indomitable hero to whose stature he aspires. Like Jason in his relentless quest or the Napoleonic-like figure of the proud Ottokar, Rustan is ruled by an obsessive will that blurs his perception of right and wrong. The same megalomania of these two

to such an extent that he immediately redirected his thoughts to representing the historical phenomena in König Ottokars Glück und Ende (1825). He portrays the successful campaign of the first Habsburg ruler, Rudolf I, against his intriguing and presumptuous vassal. Grillparzer perceived an objective correlative in Ottokar's hubris and in the Bohemian King's accompanying guilt and fall, for here was a ruler who shared the same fate as Napoleon. In 1826 Grillparzer returned once more to his earlier dramatic conception of Der Traum ein Leben. After struggling with the fourth act, he finally completed it in 1831. Because Schreyvogel as director of the Burgtheater had serious reservations about the play, it was not performed until 1834, more than two years after Schreyvogel's death. 
conquerors marks Rustan's own temperament, yet when put to a test of courage beyond the confines of his cottage, the "hero" is exposed as a craven coward. Through the encounter with his potential self in the dream, Rustan discovers the broad extent of his fear and remains in its grip to the very end of the play, thus creating an paradoxical situation. Because the awakened solipsist is now plagued by an enduring fear, yet can or will not consciously renounce his desires, he becomes ambivalent toward $R u h m$ and $G r o ̈ ß e$ as being desirable goals. He concocts another absolute and rather unique definition of how to secure happiness that is not merely a false generalization; it is a continuing indication of Rustan's obsession with himself. Thus, Grillparzer effectively utilizes the nocturnal fantasy to expose the confusion concealed in Rustan's subconscious. The dream uncovers not only Rustan's irrational desire for personal advancement but also his latent anxieties that impede the wish-fulfillment, at least in a safe and socially acceptable manner. Already the symbolism with which Act I ends and the dream begins is a reflection of Rustan's ambivalence toward $R u h m$ and Größe. The serpent, aglitter with gold, portends to offer him a glorious status and the happiness that he craves, yet fear of the danger aroused by the serpent hinders him from pressing forward, and he is immobilized. After the King of Samarkand is duped into believing that Rustan had killed the serpent, he offers the usurper Rustan a chance to attain the kingdom of his wildest imaginings. Rustan's impulse is to flee the dangerous delusion, but he succumbs to the deceit, whereupon he becomes enthralled by Trugbilder and proceeds to cultivate a life of lies.

Rustan is confronted by the inner truth of his being throughout his dreamquest to enjoy "der Größe Glück", but following the dream there is scant evidence suggesting that Rustan will not continue living in the shadow of appearances. He continues to deceive himself as he redirects his passion away from the exalted goals that he coveted in the grand world of Samarkand, which he now senses as being personally "gefährlich", toward a new fixation on possessing happiness in the safe haven of his cottage. The post-dream or so-called "New-Rustan" might aver happiness with a life of moderation, yet his previous actions have proven that his unsettled temperament is not easily reconciled to an inglorious fate. He is unable to enjoy "des Innern stiller Frieden" that permeates the quiet, unadorned life of ordinary people like Massud and Mirza. Rustan's eleventh hour praise of tempered ideals is a new set of duplicitous images, Trugbilder that conceal Rustan's repression of the same intense desire that had propelled him from one disaster to another throughout the drama, namely his wish to be a worthy object of apotheosis. The dream experience showed Rustan that his thesis was untenable, for it had falsely led him to believe that were he to secure fame and fortune, he would be held in popular esteem and his happiness assured. Yet after his old formula proves inadequate, Rustan manages to come up with another one that is 
equally incorrect. Rustan's fervent wish to transcend his lowly station in life had precluded any recognition on his part of the redeeming features of such a life. The "New-Rustan" leaves us with the impression that his attempt to reconcile himself with "die Hütte", which symbolizes existence within an uncomplicated, idyllic, and apolitical Biedermeier-like-world, is once again mere "Schein". With a seemingly high degree of certitude, Grillparzer's protagonist theorizes that happiness is attainable solely through adherence to the prescriptions of his new formula, but analysis of the play as a whole makes it evident that Grillparzer's ideal would not envisage a universal cult of domesticity, as favoured by the socalled "New-Rustan". Rustan is indeed an ordinary cottager, whereas the exalted poetess Sappho is not, and nevertheless Grillparzer measures the existential value of their respective lives with the same ethical yardstick. He gauges each individual's fundamental need, regardless of one's station in life, to live honestly in both word and deed, as well as in total accord with one's inner or spiritual being. The imperative - beware the façade-self! - is a recurring motif that the poet sounds in the foreboding message of the dervish's song and dramatizes in the negative images of the dream; the need for such caution is integral to Grillparzer's conception of his drama.

Goethe postulated that any exegesis of a work of art should begin with its title, and it is obvious from the deliberately juxtaposed pair of nouns in Der Traum ein Leben that Grillparzer was concerned with his protagonist's actions and reactions within these two differing states of mental cognition. The title already intimates that demarcations might sometimes be indiscernible between the dream world and the rational world of free and conscious choice, which is at the root of Rustan's problem. Calderón de la Barca's drama La vida es sueño was an acknowledged source of inspiration for Grillparzer. ${ }^{11}$ Grillparzer had partially translated Calderón's work as Das Leben ein Traum in 1814. Hence, Grillparzer's reversal of these two modes of awareness in the title of the finalized version of his own dream-play is conspicuous, for here the state of fantastic appearances assumes primacy. ${ }^{12}$ As a matter of fact, by first conjoining the dream with $a$ life yet without separating the two appellatives by any mark of punctuation, and by then assigning a definite article to the dream state but only an indefinite article to the

11. For a treatment of this influence see Walter Naumann, "Grillparzer und das spanische Drama", Deutsche Vierteljahresschrift 28 (1954) pp. 342-272.

12. Originally, the play was supposed to be entitled Traum und Wahrheit, but the first act appeared in print under the title Des Lebens Schattenbilder in the Taschenbuch für Schauspieler und Schauspielfreunde für das Jahr 1821. Grillparzer again makes a reference to his work in a diary entry from the year1822, yet he changes the plural noun in the title to the singular, Des Lebens Schattenbild. A second diary entry from this period, probably written in 1823 , again makes brief mention of the play, but here makes use of the present title. 
conscious life, Grillparzer's title revisions suggest that the intended dramatic approach in his rendition will lend credence to the notion that Rustan is a much more active participant in the world of private fantasy; ${ }^{13}$ and indeed the solipsist, dangerous subjectivist, and megalomaniacal egoist Rustan is a dreamer in every sense of the term. He is neither capable of fettering his desires nor ridding himself of his grand delusions, and, therefore, of controlling the direction of his destiny. In this regard, the poet conceives the symbolic dream as being an existential test. From the outset to the conclusion of the drama Rustan is beset with the existential problem of defining himself, which he tries to do in vain. His preposterous attempts at personal advancement and the dualism in his personality result in symbolic destruction in the dream. In the workings of everyday reality which the figments of Rustan's imaginary dream-world cannot obscure, the realization of his happiness - or at least avoidance of its opposite - is contingent upon his capability not to confound the two spheres. However, given the irresolute dreamer's repeatedly unsuccessful attempts to disguise his limitations, it is probable that Rustan will fail to rid himself of his desires for personal recognition beyond the dream.

It is the omnipresent fear that he might fail to reach his goal of "Größe" that causes the dreamer to decry early on how he was cruelly "losgerissen von der Heimat", from a life of idyllic tranquillity that was underpinned by Mirza's true love (1424 ff.); subsequently, the conviction that he indeed is a failure drives the anxiety-ridden Rustan from the dream-world and forces him return to the security of the cottage-world. At no point however, neither before, during, nor after the dream, is Rustan ever motivated to act out of a sense of moral rectitude. He is the prototype of the selfish individual to whom the cliché of wanting to have it both

13. Calderón's hero-prince Sigismund is deluded by faulty perceptions as he attempts to sort out what is real and what is genuinely meaningful in life. Upon being liberated from a long period of incarceration, Sigismund senses that the splendid regal life outside the tower is like a fairy-tale dream come true. Calderón's existential probe into what constitutes the basis of reality no doubt worked its way into Grillparzer's consciousness as he grappled with the issue of how one might best find "des Innern stiller Frieden" or, conversely, avoid despair. Sigismund initially seems fated to move within an orbit of psychological turmoil, yet Calderón gradually makes it clear that predestination plays no part in the life of his hero. As a Catholic, the Spanish poet's adherence to a religious belief in the freedom of the will dictated against his trying to foreordain the hero's behaviour. Although Calderón likewise plunges his protagonist into a quagmire of confusion, the optimistic Spanish playwright nevertheless endows his positive hero with a formidable mental capacity to distinguish between appearance and reality. Unlike the constantly deluded Rustan, Sigismund learns how to control his emotions and finds happiness by removing the psychological impediments to his ultimate well-being. 
ways aptly applies. He judges what is right in purely subjective terms and according to his whimsical mood. Neither at home in the mundane world of cottage and plow, nor in his imaginary realm of personal greatness, Rustan pursues his quest for happiness in confused half-measures. He lacks a sense of responsibility and accountability, and it certainly would be "märchenhaft" to assume that Rustan's fear-induced pledge of allegiance to the ways of the cottageworld will help him to act in a psychologically integrated fashion. Whenever fear induced the feeling that he was down on his luck, the Dream-Rustan was quick to blame Zanga. He thus accuses his Doppelgänger of having snatched him from a bucolic world of unpretentious joys, the very same world which at all other times he regards contemptuously as being far too narrow for the likes of a person of his noble stature. As it becomes obvious to the Dream-King of Samarkand that Rustan is not at all what he initially appeared to be, a constricting fear takes hold of Rustan, and the virtually programmed reaction of this anti-hero is to express nervous regret for ever having allowed Zanga to lure him into seeking happiness through fame, the "Gaukelbild" of his insubstantial desires, the will-o'-the-wisp of his illusory dreams:

O hätt ich, o hätt ich nimmer

Dich verlassen, heimisch Dach, Und den Taumelpfad betreten, Dem sich Sorgen winden nach.

Hätt ich nie des Äußern Schimmer

Mit des Innem Wert bezahlt

Und das Gaukelbild der Hoffnung

Fern auf Nebelgrund gemalt.

Wär ich heimisch dort geblieben [...] (1497-1505)

Hollow confessional outbursts such as this one usually last no longer than the scant time that it takes Rustan to utter the sentiment, for he contradicts them in his next breath:

Ha, und doch, zurück es lassen,

Was mir anbeut das Geschick?

Diese Stadt mit lauten Gassen,

Eines Reiches fürstlich Glück

Wornach heiß mein Wunsch getrachtet,

Leibhaft, wirklich schau ichs an

Und beim Griff der Hand umnachtet

Mich ein gaukelhafter Wahn?

Standen nicht der Vorzeit Helden

Oft auf gleicher Zweifelbahn? (1509-1518) 
He thus not only negates his professed longing to return to the "heimisch Dach" of the cottage, but also glorifies further continuation of his journey on the same path from which he wished to exit. What is wrong in one instant is absolutely correct in the next. The world of his dreams that Rustan repeatedly affirms as real is always false; the "Taumelpfad" that he presumes to be the right one for him will lead him in the wrong direction.

In his dream quest for spiritual fulfillment through fame and fortune, Rustan deems wishful thinking to be a source of greater substance in his life, and on the invidious scale with which he weighs the two existential possibilities, "counterfeit life" against "genuine existence", he reduces the latter to a world of tricks, delusions and lies. Calderón endows his protagonist with great clarity of thought which enables Sigismund to loose pent feelings of rage and frustration and supplant them with the rational desire to live out the remainder of his life in a spirit of moderation. As the Spanish dramatist's play concludes, his hero luxuriates in what for Grillparzer was the most sublime state of human existence, "des Innern stiller Frieden". Unlike Rustan, Sigismund is not directed by an insatiable will. He represents a man of true accomplishment as he progresses steadily toward that inner peace which Grillparzer so highly prized. Sigismund is no Tatmensch, no self-serving counterfeit-hero unable to use his powerful position judiciously. Conversely, Rustan is no Sigismund, neither by virtue of a noble birthright nor a stable mental disposition, and so in Der Traum ein Leben Grillparzer chose to show his audience the other extreme. Rustan's craving for personal recognition exceeds his actual potential for legitimately achieving the goal; valorous deeds warrant a greater ability than Rustan has to accomplish them. Consequently, as Zanga nourishes Rustan's ambition through his assertions that Rustan was born to greatness despite his rustic origin $(296-298 ; 408-410)$, the "Taumelpfad" on which the inept adventurer seeks fame by attempting to become the sovereign of Samarkand becomes increasingly crooked. With enticing tales of conquest, the "Negersklave" of the outer frame stokes the fire of abnormal ambition already present in Rustan's psyche, and as dream evolves into nightmare, Zanga's status alters. The Dream-Zanga who is essentially disposed toward all forms of mendacity -"Schwarz gekommen schon zur Erden, / Darfs nicht erst durch Lügen werden" (1195f.) - is delineated with features that eclipse the reality of the servant. The Dream-Zanga mirrors Rustan's increasingly selfish will. In his quest for power within the dream, Grillparzer's protagonist repeatedly submits to the delusions of his seducer. By readily availing himself of Zanga's treachery, Rustan becomes equally devious, for his desire to transcend his lowly station in life has obscured his psychological clarity and sapped him of the moral fortitude needed to resist the malevolent temptations of his potential self. In viewing the Dream-Zanga's metamorphosis symbolically, it is apparent that Rustan's twisted psyche is responsible for the telltale transmogrification of his alter ego into a 
demon who stands before him with black wings and snakes for hair.

Zanga's function of kindling the flames of Rustan's unrealistic desires is reminiscent of the attempts of Goethe's Mephistopheles to make Faust affirm the life sensuality as one of enduring value. Zanga's bitter sarcasm whenever Rustan falters also echoes a note found in Goethe's Faust, but whereas Goethe's Mephisto fails to understand that Faust's aspirations are cosmic and rooted in his complex curiosity, Grillparzer's diabolic blackguard is fully aware of the inept Rustan's petty concerns. Regardless of the cost to others, Rustan's hunger for personal advancement must be sated. Zanga understands that Rustan will succumb to his wiles for a chance at worldly success, even if it entails no more than possessing the mere external trappings of power. Zanga accurately denigrates Rustan's desires to sheer lust after personal, worldly glory, and he ridicules him as a "schwacher Schüler" when Rustan fails (2463). If Faust as "ein guter Mensch in seinem dunklen Drange, ist sich des rechten Weges wohl bewußt", then Rustan is the Faustian antithesis; a deluded hero who is incapable of dealing with the basic problem of good and evil on the personal level, let alone of intellectually wrestling with the broad question of the capacity of knowledge to provide mankind with the ultimate secrets of the universe. Rustan spurns the thought that he was not born to be great, and the dream provides him with a fleeting means of escape from his unattractive destiny and insufferable ennui. After the dream images have dissipated, it seems that Rustan is granted what was denied Goethe's Faust, namely the chance for a meaningful life with a loving wife, and freedom from mental anguish through love. Yet Rustan shows little promise of being psychologically capable of cherishing these blessings. There is no substantial evidence in the play that can attest to the fact that Rustan has defined his true identity. Beyond Rustan's abrupt statement brought on by his apprehension, in which he declares that he now knows how to acquire an unimpassioned heart or "des Innern stiller Frieden", there is no verification that he will succeed; and Grillparzer's prerequisite to finding inner peace and happiness is precisely "die schuldbefreite Brust". Therefore, not only the dream itself but the action beyond the dream, in effect the play in its entirety, can be seen as a survey of moral failure resulting from Rustan's inability to define himself.

When the Dream-King first tried to determine who had saved his life, Rustan is made to kneel in the distance ( $\mathrm{SD} / 842$ ). Thereupon, Rustan's dark self interrupts the half-hearted efforts of his "master" to admit that he had failed to kill the serpent, notably in a series of lines of broken verse. As he completes Rustan's sentences, Zanga characteristically distorts the truth (849-50), and when fear overpowers Rustan, prompting him to advocate a quick retreat from the dangerous complication (856), Zanga counsels him that the time for harvesting fame, wealth and power has just begun: 
Nach dem allen, Herr, und fliehn?

Jetzt, da unsre Bohnen blühn? (857-858)

Rustan pompously retorts that he could never allow himself to be praised unjustly, but then, as usual, he proceeds to contradict himself. Time and again we detect how Rustan's occasional outbursts of seeming moral indignation reflect his identity crisis, for as Rustan himself admits, having once received the praise he covets, he no longer is able to bear the thought that he might have to yield his place to a rightful other:

Nimmer sollst du mich berücken,

Mich mit fremder Tat zu schmücken.

Und doch könnt ichs auch nicht sehen,

Erst gepriesen, erst gehuldigt,

Zager Feigheit dann beschuldigt,

Einem andern nachzustehen. (859-864)

Whereas Zanga is intent on reaping material rewards, the "Bohnen" or tangible wealth of which he speaks has no appeal to Rustan who instead craves recognition within high spheres to which he is ill-suited. As long as Zanga's enticements are focused on material gain, they remain unalluring to Rustan and need not be resisted. Consequently, Rustan can briefly talk himself into believing that his moral fabric is made of sterner stuff, which he manages to do only until he is beset by the question of self-promotion. When he first espies the princess Gülnare (869), "eine Lichtgestalt" who dubs him noble and bids him welcome to the world of "Größe" and the kingdom of his yearning, Rustan's attitude changes drastically:

\footnotetext{
Vater, schau, so sehen Helden,

Vater, schau, so blickt ein Mann.

Was uns alte Lieder melden,
}

Schau es hier verwirklicht an. (908-911)

Rustan finds Gülnare's vision disconcerting. It touches a sensitive nerve, for it makes him aware of the fact that he is but an empty shell of the heroic man whom she envisages as now standing before her. Nevertheless, having once been accorded a bit of recognition in the land of his dreams, albeit for heroic deeds not of his own doing, nothing can check Rustan's will to advance himself in the great world. The flattery of the princess leaves him "selig" (1020), and as his rapture waxes, his already stupefied sense of reason becomes even more prone to accept her erroneous judgment of his worth as correct. While giving himself over to the tyranny of agreeable appearances, he becomes progressively enveloped in growing 
emotional turmoil. Rustan's attempt to explain away the brown-cloaked figure who actually slew the serpent and saved the King's life as a probable "Bote einer höheren Macht" (1032) is one more Trugbild. Rustan might have a tenuous grip on reality, yet his readiness to succumb to the charming delusion of divine intervention is not the working of a psychotic mind. Thus, Rustan is quick to add that should the brown-clad man who helped him in that trying moment prove to be someone other than an envoy from heaven, he would be prepared to make him rich and famous. Even though he begins to rationalize his calculated wrongdoings: "Und wer wirft mir Unrecht vor? / Zanga, denn was ich gewinne, / Ist nicht das, was er verlor"(1044-46), Rustan remains morally responsible for each of his deeds, for his inner self is obdurate in its refusal to accept Rustan's false projections of personal grandeur. This subconscious truth prevents him from giving himself over fully to the delusion that he is a man whose actions are in step with those of an authentically heroic existence. Try as he may, Rustan is unable to fool himself completely. In their confrontation, Rustan entreats the drably dressed man not to displace him and begs for the chance to perpetuate the lie. However, this symbolically clad accuser who functions as Rustan's truthful alter ego, Zanga's antithesis, warns the narcissistic Rustan to rid himself of his vanity forthwith (1120-1123). Once again Rustan spontaneously acknowledges the truth imparted by his symbolic voice of conscience, yet true to form he follows the affirmation of truth with a typically abrupt contradiction. In a series of rapid exclamations, Rustan rejects the thought of returning home again: "In der Nahverwandten Mitte / Sei das Glück der ersten Schritte, / Sei die Schmach-und dennoch! -Nein ! / Nein es darf, es soll nicht sein!" (1126-1129). As the personified antagonist to Rustan's hypocrisy attempts to traverse the same bridge equated by the dreamer with his personal path to freedom and fame, and, thereby to relay the message of Rustan's existential truth, violent reactions erupt within Rustan's psyche. He destroys the man-in-brown who wants to win him over to reason. He hopes to forever still the voice that would bring him the unacceptable message that he is unsuited to living the celebrated life. In effect, he tries to repress the veracity of his being, his true identity as an ordinary mortal who is lacking in extraordinary ability. In a state of desperation heightened by Zanga's urgings, the impostor Rustan attempts to silence his moral conscience by plunging its symbolic embodiment from the light above into the darkness and stillness of the stream below.

Borders gradually efface between who incites and whom is incited to immoral action. Whereas Zanga initially goads Rustan to destroy anyone (people) or anything (his identity) that might block the path to power and glory, Rustan's personal responsibility for the rising swell of evil deeds is increasingly evident as the dream progresses; and further along into the dramatic action, Rustan becomes the commanding evil presence. It is Rustan's diabolic voice that is heard 
whispering to his dark companion to do away with Kaleb, the father of the manin-brown whose murder Zanga had previously incited Rustan to commit. Old Kaleb, another symbolic representative of the existential truth that Rustan will not accept, is the dream-correspondent to the dervish of the drama's outer frame. In his telltale reverie Rustan relegates Kaleb's status to that of a dumb mute, and since he cannot vocalize his thoughts, it would appear that he should be less able than a singer of songs to trouble the hypocrite. However, once again Rustan fails to silence the message that communicates his guilt. The "hero" panics when Kaleb resorts to non-verbal means in order to bring the truth of his son's murder to light. Kaleb emerges as an equally disturbing psychological presence who calls Rustan to account for his immoral deeds. As was his drably attired son, Kaleb is a symbolic reminder of the futility of Rustan's persistent attempts to secure personal contentment while repressing the fundamental truth of his being. He is not allowed to forget that his pretensions will bring about unhappiness. The deceptive self-portrait of a hero that Rustan had created was still vivid in his imagination as he entered the dream world immediately after turning a deaf ear toward the dervish's intonations against the vanity of his ambition. Thereupon Rustan's escape from the humble cottage-world into the realm of reverie seems to be met with a limited degree of success. Despite his fleeting semblance of grandeur, the Dream-Rustan gradually becomes riddled with fear, for as each symbolic representative of Rustan's existential truth relays the message that Rustan is not competent to retain what he has gained illicitly, the pleasant illusion is transformed into a nightmare. He dreads the thought that he will have to abandon the domain of dreams and relinquish "Ruhm und Größe" for his erstwhile life in the simple, unexciting cottage-world. In the thrall of his irrationality, Rustan endeavours to brutally silence each of the voices of truth that offer testimony which could result in his fall from power (2020-2025). By attempting to extinguish the sounds of reason one by one, Rustan would mute the inner voices of his own existential truth forever, but these foolish efforts only entangle him further in the net of his paranoia.

A statement dating from October 1819, in which Grillparzer articulates in a general way the negative value of Jason's quest and his means in obtaining the golden fleece, can be applied to Rustan's desire to gain happiness through selfaggrandizement. In both instances, the men are motivated by "Ehrgeiz". Their insane ambition drives each of them to commit a succession of violent acts from which there is no escape, and they forge a chain of evil through their progressive acts of injustice: "Das eben ist der Fluch der bösen Tat, daß sie, fortzeugend, Böses muß gebären [...] Das Vlies ist nur ein sinnliches Zeichen dieses Satzes. Es ist da nicht von Schicksal die Rede. Ein Unrecht hat ohne Nötigung von außen das andere zur Folge [...]".14 As Grillparzer's stage demonstrates, "Schicksal" is 
the immediate result of a fatal flaw in the protagonist's character, and in Rustan's case, his freedom of choice is nullified because he is easy prey to the unrealistic "Wünsche" and malevolent "Taten" against which the poet cautions through the dervish's song. Rustan's fixation on personal success in the great world enmeshes him in a web of immoral activity, wherein he inevitably is doomed to commit more base deeds. Wanting in the qualities needed to realize his aspirations of leadership legitimately, Rustan resorts first to unscrupulousness in order to gain power and then to tyranny in order to retain it. He refuses to accept a basic fact of all human existence, namely that regardless its intensity, desire will not transform the unrealistic dream into reality. Rustan will not accept the world into which he was born as his own, even though the world of the cottage and the plow is the sole place where he might reasonably acquire a respected if not elevated status within the community.

Massud's direct characterization of Rustan at the play's outset sheds substantial light on Rustan's psychological instability. The sage depicts the young man as being filled with a crazed passion to elevate himself through battle. He alleges that his nephew's personality and bellicose behaviour result from his constant fantasies, and he stresses how Rustan's dreams of conquest are irreconcilable with his own and his daughter's gentle ways:

$\mathrm{Ja}$, fürwahr, ein wilder Geist

Wohnt in seinem düstern Busen,

Herrscht in seinem ganzen Tun

Und läßt nimmerdar ihn ruhn.

Nur von Kämpfen und von Schlachten,

Nur von Kronen und Triumphen,

Von des Kriegs, der Herrschaft Zeichen

Hört man sein Gespräch ertönen,

Ja, des Nachts, entschlummert kaum,

Spricht von Kämpfen selbst sein Traum.

Während wir des Feldes Mühn

Und des Hauses Sorge teilen,

Sieht man ihn bei Morgens Glühn

Schon nach jenen Bergen eilen.

Dort, nur dort im düstern Wald

Ist des Rauhen Aufenthalt [...] (85-99)

"Des Rauhen Aufenthalt," is a coarse realm that lies beyond the ordered, refined

14. Sämtliche Werke, historische-kritische Gesamtausgabe, Sec. 1, Vol. XVII, p. 301; for an argument that convincingly demonstrates how Ehrgeiz rather than Begierde motivates Jason, see T.C. Dunham. "Symbolism in Grillparzer's Das Goldene Vließ", PMLA, LXXV (1960), pp. 75-82. 
and civilized world of Massud and Mirza. Symbolically, it is located in the recesses of Rustan's own disturbed mind. "Des Rauhen Aufenthalt" offers none of the repose, "des Innern stiller Frieden", that pervades the sphere where unassuming, humble human beings are active; and absent in Massud's nephew is a quiet spiritual harmony, which for Grillparzer is not only an essential condition for genuine happiness on this earth, but also for greatness in its soundest form. When Zanga advises Rustan early on in the play that henceforth he must deny his true identity by disavowing his humble origins and ennobling his lowly father, Rustan laments loudly for the "arme Mirza!". Yet the response of Rustan's dark, intriguing alter ego, "Ja, weil arm, /Hindert sie ein reiches Wollen" (724f.), reflects Rustan's confused emotional sentiments and psychological impoverishment. Indeed he cherishes Mirza in his fashion, as his attraction to Mirza's dream-correspondent Gülnare attests, yet he will not relinquish the delusion of eventually being able to transcend his limited station in life. Moral action and the possibility of becoming truly happy are retarded by Rustan's irrational will-to-power.

Prior to his dream, Rustan had derided the simple life as being dreary and dull - echoed in the garb of the drably-clad cliff man - because of a feeling that a titan was lying dormant within him. Rustan rejects the idea that destiny has consigned him to live out his days in the cottage-world as well as the possibility that any meaningful life might be led therein. All the tomorrows that an unimpassioned life purport to offer hold for him only emptiness in store: "Wie so schal dünkt mich dies Leben, / Wie so schal und jämmerlich. / Stets das Heute nur des Gestern / Und des Morgen flaches Bild "(279-282). He envisions a glamorous life in which he would live close to the heavens like a god and listen to the melodies of heroic songs: "O, es mag wohl herrlich sein, / So zu stehen in der Welt / Voll erhellter, lichter Hügel / Voll umgrünter Lorbeerhaine, / Schaurig schön, aus deren Zweigen, / Wie Gesang von Wundervögeln , / Alte Heldenlieder tönen [...]" (299-305). In his wildly extravagant depiction of himself as Übermensch, Rustan arrogates to himself a totally false identity:

Starker, nimm dich an der Schwachen!

Kühner wage! Wagen siegt,

Was du nimmst, ist dir gegeben!

Sich hinabzustürzen dann

In das rege, wirre Leben,

An die volle Brust es drücken,

An sich und doch unter sich.

Wie ein Gott an leisen Fäden

Trotzende Gewalten lenken;

Rings zu sammeln alle Quellen, 

Die, vergessen, einsam murmeln,
Und in stolzer Einigung,
Bald beglückend, bald zerstörend,
Brausend durch die Fluren wälzen. --
Neidenswertes Glück der Größe!
Welle kemmt und Welle geht,
Doch der Strom allein besteht. (309-325)

By equating himself here to a mighty river, Rustan suggests that he is like the powerful "Strom". However, he also exposes his despotic inclinations. One discerns from Rustan's metaphorical equation how his petty tyrannical spirit would engulf and decimate all those with whom it comes into contact; and indeed, when Rustan's ambitious will is finally unleashed in the dream, he seeks to absorb, destroy, and efface the identities of all the people who are subject to his harsh determination. Rustan's emotional insistence on immediate gratification, which even the calculating Zanga finds problematic at times (290-291), resembles a raging flood that defies any attempt to channel it along a true and sensible course. Only the product that Rustan's insatiable will demands, but never a fitting process of attaining it, is of value to this dreamer. In his frenetic pursuit of happiness, Rustan is driven on blindly by distorted dream-images that negate his chances to posit a genuine existence.

For Rustan, freedom should mean happiness. However, the dream that should satisfy Rustan because it offers him the boundless, intoxicating freedom for which he has thirsted turns out to be a sobering experience. As the fantastic dream-world takes shape, Rustan compares his new state of being with that of a bird who can finally venture forth from the closed nest. As it experiences its first flight, the jubilant fledgling bursts into song :

Nicht mehr in dem Qualm der Hütte,
Eingeengt durch Wort und Sorge,
Durch Gebote, durch Verbote;
Frei, mein eigner Herr und König!
Wie der Vogel aus dem Neste,
Nun zum erstenmal versuchend

Die noch ungeprüften Flügel [...](657-663)

Yet Rustan's reverie which starts as a flight of fantasy becomes a distressing nightmare because of his inability to achieve his goals through licit means. Questions remain unanswered: Are we to believe that the self-serving dreamer is now able to fathom what his dream should have revealed to him, namely that a life devoid of restraint is destructive, especially when inept tyrants such as he 
condone it? Are we to believe that Rustan has suddenly perceived that further ambitious pursuit of his unrealistic hopes and dreams would be folly; in effect, existentially wrong for him? Upon his forced withdrawal from the dream-world, Rustan indicates that his eyes see the proverbial light. He admits that he has undergone a great change of heart that now allows him to view the humble cottage-world as being the more vital and rich of the two modes of existence. Thus, on the basis of the play's plot and its dramatic structure that encapsulates a colourful "dramatisches Märchen" within the pallid, "drably attired" drama of Rustan's routine life, Der Traum ein Leben presents what seems to be a traditional, popular Viennese Besserungsstück. ${ }^{15}$ However, although Rustan's foibles seem to be corrected at the end of the play, at least superficially, appearances are deceptive, both to those who take Rustan's word at face value and to Rustan himself. Despite the fear provoked by his shocking nightmare, Rustan still demands "Glück", without once acknowledging the truth of his being.

The conclusion of Der Traum ein Leben does not provide an unambiguous resolution in keeping with the character of the "play-of-betterment". The problem of Rustan's "Zerrissenheit" which is the decisive impediment to his happiness, is never actually alleviated. The play has an open ending more characteristic of modern drama.

In the closing section of the drama's outer frame, Massud's expression of distrust regarding his nephew's unexpected allegiance is significant in assessing Rustan's apparent psychological change. Previously, Rustan had fulminated against Massud's modest values. His uncle had been made to suffer Rustan's repeated derision of the quietude of his and his daughter's life. "Diese Ruhe", Rustan had maintained, "diese Stille, / Lastend drückt sie meine Brust" (533-534). Rustan grumbled about how cottage-life was incongruous with his own destiny and condemned their humble place as one where he never could become "eigner Herr und König". He regarded his uncle's world as a safe but inhibiting nest. Thus, the unexpected encomium of the quiet cottage-life that emerges directly on the heels of his nightmare is ironic, for it is in this constricting "nest" that

15. Grillparzer is clearly interested in incorporating the elements of the popular stage into a psychological process, and thus Yates points to the fact that the actual coming of sleep is shown by the use of allegorical figures who represent real life and dream life. As Rustan's dream begins, the figure representing real life is suggestively dressed in drab garments," in braunem Gewande"; while his torch is used to ignite that of a brightly clad figure, "buntgekleidet", whereupon its glow is extinguished. Thus, the dream is not the product of any simplified magic spell that one finds in traditional Zauberstücke the dream is realistically conceived and then motivated by the transfer of "the effects of magic into the effects of a credible psychological process". W.E. Yates. Grillparzer. A Critical Introduction. Cambridge 1972, p. 117. 
Rustan now seeks refuge. The baffled Massud cautions Rustan to exercise prudence in his future actions, yet finds an even greater need to admonish his nephew not to forget that dreams are simply projections of personal wishes. Massud interprets the dream as a revelation of what lay repressed within the dreamer's subconscious mind:

Doch vergiß es nicht, die Träume,

Sie erschaffen nicht die Wünsche,

Die vorhandnen wecken sie,

Und was jetzt verscheucht der Morgen,

Lag als Keim in dir verborgen.

Hüte dich, so will auch ich. (2696-2702)

By warning his nephew against his aspirations which can only lead to a life of deception, Massud is advising him to learn about himself and to accept his limitations. In effect, he is imparting the same age-old wisdom contained in the message of the dervish's song that Rustan once rejected. Prior to the dream, Massud had witnessed how Rustan always seemed to experience "Schein", the fantasy world of heroic appearances with far greater immediacy than "Sein", the joys that come from living genuinely and working honestly each day for a common purpose; and in his dream Rustan does relate to the dream-figures with an emotional intensity surpassing that which characterizes his dealings with actual people who are made to suffer real sorrow at his hands. Massud intuits that the vivid and shocking dream has not corrected Rustan's distorted view of life. His nephew's sudden change of heart is of greater concern than ever to him, for Massud is confronted with the unpleasant prospect of finally entrusting his daughter to a man who time and again has proven himself to be "wild", madly irrational and savagely irresponsible.

The "New-Rustan" claims to know wherein mankind's happiness lies, yet the dreamer did not leave the fantastic realm of Samarkand as the result of having understood the folly of his ambition. It was fear alone that forced him to exit. Furthermore, even if no consideration were given to the argument that Grillparzer never intended to champion the humble cottage-life as the locus of universal happiness in Der Traum ein Leben, it is not reasonable to assume that a man who has consistently exhibited the negative characteristics of Grillparzer's egoistic anti-heroes should abruptly become the spokesman for the poet's ethical absolute. Rustan's simple and ordered formula for happiness is thoroughly inconsistent with his iniquitous behaviour throughout the play, and although Massud's uncomplicated life appealed to Grillparzer, he did not regard "Größe" as an ethical liability for all men. ${ }^{16}$ What mattered most to Grillparzer was his task to

16. Grillparzer would agree that the initial part of Rustan's statement is axiomatic, namely that "Eines nur ist Glück hienieden, / Eins, des Innern stiller Frieden / Und 
communicate the universal need for people to lead their lives free from deception, but most especially from self-deception. The basic principle of reason that governs both Massud's unadorned life and the life of his regal dream-correspondent is lauded by the poet as the signifier of truth and genuine existence. However, since Rustan has never willingly acquiesced to rational demands, his ungovernable will and unrealistic ambitions continue to be the main source of his uncle's ongoing concern.

A subconscious voice in the awakened Rustan murmurs the dream-awareness of his likelihood for further failure, yet it is unable to transmit a more perfect understanding of the poet's message already contained in the dervish's song, namely that base elements in his nature should not be given free rein so as to be able to drive him into denying the truth of his being. His ambition at the play's outset had spurred Rustan on in quest of illusory goals that promised happiness and fulfillment, but in the end a proportionately fearful awareness of failure keeps him from continuing on in their pursuit. Although his fear might momentarily hold Grillparzer's anti-hero within the security of the cottage-world, it is not sufficient in itself to convey to Rustan the value of an honest, gentle and rational life.

The dreamer's view is antithetical to that of the dervish's Wahrheitscredo, namely Grillparzer's own moral advocacy. Even at the end of his fantasy, Rustan is frustrated only because fear prevents his clinging further to the illusion that his destiny is to be a grandseigneur. Here Rustan is stricken with horror when his alter ego appears as a hellish demon (2510-2518), yet his dismay stems from the recognition that he had been denying the truth of his being in favour of a façadeself. If the dream was meant to be a test, then Rustan has failed in more ways than one. Zanga's final evaluation of his performance takes the form of an outright rebuke, where Rustan is graded as incompetent (2463). The masterdeceiver assesses the endeavours of his "Schüler" as having been feeble at best, the efforts of a bungler unable to elevate himself above his station in life because he is a flawed vehicle:

Wolltest du der Herrschaft Sprossen,

Du den steilen Weg zum Großen,

Du erklimmen Macht und Rang?

die schuldbefreite Brust [...]; but the poet would not concur with what follows, namely that in and of itself "die Größe ist gefährlich, / Und der Ruhm ein leeres Spiel [...]". Grillparzer recognized that there were individuals who were born with a genuine calling and commensurate ability to change the world for the better, and the poet never took it upon himself to trivialize their deeds. Rustan, however, represents all the sham heroes. Since their aspirations to "Größe" are unrealistic and dangerous, "Was er gibt, sind nichtge Schatten, / Was er nimmt, es ist so viel". 
Bunt gemengt aus manchen Stoffen

Ist das Roherz der Gewalt [...]

Doch du konntests nicht ertragen,

Eng der Sinn, das Aug nur weit,

Willst du siegen, mußt du wagen:

Kehre denn zur Niedrigkeit! (2414-2429)

Zanga echoes Osmin's sentiments along with those of his drably attired dreamcorrespondent. Both derided Rustan's capacity for notable achievement beyond the cottage-world due to his his meagre talent. Rustan's mind transforms Zanga into a dreadful "bad angel" as a result of Zanga's appraisal of him as a country bumpkin unable to achieve his high hopes.

Thus the "New Rustan" does not act out of a fresh, rational and moral conviction that unrealistic desires and false dreams were leading him astray. Much to his chagrin, he instead has been made to sense his impotence and cowardice by the repeated confrontations with the various representatives of his subconscious. Yet Rustan's most serious failure occurs in the closing half of the drama's outer frame, when he still shows no sign of being able to decipher the missive that links self-cognition to happiness. After initially rejecting the message in the dervish's song, the warning reappears time and again in Rustan's dream-content, and in the wake of the dream it continues to go unheeded by the "New-Rustan". To be sure, he senses that Samarkandian greatness is beyond his reach, yet he has not solved the problem of his identity. Rustan has gained an awareness of what he is not, but little insight into what he is. Existentially, the "New-Rustan" resembles a sleepwalker, a being "no longer" fully anaesthetized by sleep, yet one "not yet" quite awakened to the surrounding reality. The confusion that has plagued the restless and ambitious dreamer in his misguided quest for personal advancement and his failure to define himself will continue to impede his recognition of the positive values that an unpretentious life has to offer, and, therefore, from knowing true contentment. In effect, the not-so-new Rustan will be denied a truthful answer to the essential question of the drama, "Was ist Glück?".

The conclusion of Der Traum ein Leben does not make clear just how long Rustan can suppress his inner conflict, yet it does reveal that the fearful dream has not purged the anxiety-ridden dreamer of his irrationality and irresponsibility by a process of Bildung. The Dream-Rustan protested vociferously against the reversal of fortune which compelled him to cross the bridge of dreams and return to the humble world of Mirza and Massud, and in this regard, his contradictory declaration of peace with the cottage-world sounds hollow. In the closing exchanges with the Dream-Zanga, Rustan's diabolic alter ego informs him that no choice remains other than to forsake this realm of fantasy, if he wants to save 
himself from the wrath of the Samarkandians whom he has wronged. Yet although beset by anxiety, Rustan is unequivocally opposed to reentering the moral, humble life that awaits him:

Zanga: Siehst du dort die dunkle Brücke?

Sie, der erste Weg zum Glücke,

Sei nun auch des Unheils Pfad.

Rustan: Weh mir, weh.

Zanga auf die Brücke zeigend. Nach dorthin flieh.

Rustan: Nimmermehr betret ich sie. (2487-2492)

The landscape of Rustan's soul romantically portrayed at the opening of Act II has been transformed into a potential battlefield where he is filled with fear. Malicious deeds have led him to inevitable failure, and yet it is not failure per se but rather the sense of dread posed by the threat from the Dream-Army of Samarkand that causes him to flee. He sees his chance for personal recognition in the great world gradually slipping away. The would-be-hero fears a confrontation with his just pursuers who are demanding retribution, knowing that he will be exposed as a failure and must perish as a fraud. Rustan indicates that were he given a second chance at existence in his fraudulent world-of-fantasy, he would prefer abide there in pretentious greatness rather than become existentially genuine in the quiet surroundings of the cottage. He finds the demands of Entsagung abhorrent because they dictate that he relinquish his unrealized ambition and return to the cottage-life into which he was born; but Rustan's sole choice is to comply. Therefore, since the rankling discord in his soul is never stilled upon emergence from the dream, the possibility of Rustan's finding happiness through spiritual peace, "des Innern stiller Frieden", seems more remote than ever.

Given the tenets of the Besserungsstück, one could believe that a positive correlation exists between Rustan's plunge from the bridge and his moral adversary's earlier fall from this very same location. Just before being toppled into the stream below and while in the throes of death, he laments the death of childhood innocence as he cries out Rustan's name in conjunction with Mirza's (1146-1148). However, recapturing the lost innocence of early youth is not consonant with Rustan's ambition to be esteemed as a "man-of-action". Likewise, no moral principle connects the wisdom of the poet's spokesman of truth with the utterances of the unenlightened, anxiety-ridden "hero" as he greets the brightness of the morning sun in the immediate aftermath of the menacing dream. Like the previous case when he entered the dream-world, the "New Rustan" now imagines a new day that will provide him with happiness, and "Was verworren war, wird helle"(2636). Yet Rustan has merely succumbed to another "Trugbild". His fall from the bridge that he had envisisaged as his personal threshold to fortune (11301133) was no symbolic descent into baptismal-like waters which would redeem 
him by cleansing him of his bent to self-deception. Neither his numerous encounters with positive and negative alter egos in the symbolic dream, nor the dream-images themselves that reflect how continued fantasizing will be disastrous for him in real life, have purged Rustan of his perpetual discontent. His tribute to tranquillity is a rationalization, another of the many Trugbilder. For the wildly ambitious Rustan, the quiet life holds in store none of the lofty visions that he had imagined as being part of his destiny. Yet the new and schizophrenic Rustan, subconsciously aware of his paucity of knowledge and lack of fortitude to advance himself legitimately, must learn to accept the simple life within the constrictions of the cottage-world. Only in this regard is his fate ineluctable, for it leaves this flawed hero with no better choice. Consequently, the quality of Rustan's cure is very suspect and his chances for future "Glück hienieden" highly dubious.

The awakened dreamer's actions remain fraught with ambiguity. In a semiconscious state of frenzy, the dagger-wielding Rustan scares off the actual servant Zanga whom he had just envisaged in his dream as a sinister supernatural being. "The hero" is left incredulous by Zanga's flight, yet elated by his deceptive supposition that a powerful adversary views him as a formidable foe:

Er entfloh! Ich bin nicht Macht-los,

Seine Macht nicht unbezwinglich.

Und nun fort aus diesen Räumen,

Rings umstellt mit Todesgrauen.

Nur noch erst verlöscht das Licht,

Das mich kund gibt meinen Feinden. (2556-2562)

The assertion that he is no weakling is empty, since Rustan continues to delight in hallucinations rather than looking for rational explanations to real phenomena. Supposedly he is awakening to a "new life", yet he manifests the same predilection to succumb to the kind of ego-flattering Trugbilder that have previously lured him into believing that he possesses remarkable personal qualities. Granted, Rustan is now aware that he cannot rule the kingdom of Samarkand, but the familiar, unrealistic desire to vanquish and dominate have not vanished.

Ironically, the New-Rustan shuns the dream-realm as a threat. Now he exhibits the same intense anxiety that had beset the Dream-Rustan whenever fear had motivated him to seek refuge in domestic security. Therefore, since the NewRustan's valuation of the gentle life is undermined by the fact that he was forced to flee back to the safety of the cottage, what has been altered as a result of the dream is certainly not Rustan's propensity for irrational dreaming. He merely redirects his fantastic musings toward a less frightful situation. The light in the room that Rustan hurriedly snuffed out so as to conceal himself from the enemies 
of his imagination is suddenly replaced by the brightness of the sun, symbol of reason, yet within the psychological parameters of the play, it is hardly conceivable that the fanaticism unleashed within his subconscious mind by the dream has been extinguished. Rustan, whose unruly will had always fostered his agitation never recognizes that the ultimate enemy is housed within his own disturbed mind. Thus, since Rustan shows no indication of being prepared to deal consciously with the threat posed by his insatiable will to the realization of any form of harmonious existence in his future, repressing instead his far-fetched desires out of fear, this dreamer's psychological turmoil is never really quelled.

Traditional pairs of antinomies characteristic of the Besserungsstück - black / white, dark / bright, and bad / good - inform Der Traum ein Leben, and since Grillparzer's play is an obvious derivation of the genre, a "happy-ending" would seem in keeping with the expectation raised by tradition. Then too, a number of other predominantly positive notes can be accentuated, for Rustan seems to be given a chance to extricate himself from an inchoate life of duplicity and guilt and to become "better", an opportunity that Grillparzer withheld from his other unscrupulous, megalomaniacal "heroes". The nightmare does not prove to be Rustan's nemesis, for his actions in the dream-world were mere products of his dream-psyche, and, as such, free from the threat of both moral censure and actual destruction. Furthermore, in the final scene, Massud grants Rustan his permission to marry his exhilarated daughter, while Zanga and the dervish, polar aspects of Rustan's divided soul, play music together. In a traditional Besserungsstück, the union of the two would foreshadow a new, harmonious concordance. Notably, Zanga is no longer enslaved, and having just been liberated is told to remove himself from the idyllic surroundings of the cottage-world. However, analysis that goes beyond the superficial aspects of the play reveals that justice cannot be done to the drama as a whole if these final scenes are interpreted as clear-cut representations of the idea that the darkness in Rustan's soul has been routed, and that his proclivity for confusing "Sein" with "Schein" no longer exists. The closing musical notes produced by the Dionysian flute of Zanga mingle with the strains of the Apollonian harp of the old dervish in a seeming harmony. However, the unified appearance of these two representatives of the polar elements of Rustan's psyche is qualified by the ambiguity that throughout the play has cast doubt on Rustan's ability to renounce false ambition in favour of a life that is genuine. A Besserungsstück would have the audience rejoice in the assumption that the earlier dissonance created by Rustan's identity crisis is gone, yet the playwright undermines this by visual clues. Rustan and Mirza are viewed sinking to their knees as the curtain falls, while only the tones of the dervish's music continue to be audible. Conspicuously lacking here is the song's text that praised the enduring values that inform lives that know peace because they are rooted in moral rectitude. Once Rustan had found himself echoing the song's message, yet 
he chose to dismiss the content, since it got in the way of his aspirations (636). Now the missing text cannot occasion immediate mental complications for Rustan. The problematic message is still repressed, and as long as it remains concealed, he need not contemplate its import. Rustan formulates his unique conception of humble domesticity as the source of universal happiness, but says nothing at all about how happiness is the result of truth and ethical action, those exalted values in the textual portion of the dervish's song that Grillparzer himself lauds as the summum bonum. In all likelihood, Rustan's dream of greatness has been replaced by a daydream from which neither fulfillment nor salvation will be forthcoming. Although Rustan greets the sun as the herald of his new day, here the traditional symbol of enlightened reason might more aptly be regarded as the reflection of another blinding force in an essentially flawed character; and the music with which the play ends more likely signals the outset of a new irrational dream, just as it had heralded the advent of a nightmare that seems to have brought Rustan to no moral awareness and to no "better" or higher state of being.

Der Traum ein Leben concludes with no definite indication of what is to come after the curtain falls, yet if the future is supposed to bode well for Rustan and those with whom he comes into daily contact, namely his bride and her father, then a palpable reason for Rustan's having acquired a sudden ability to overcome his Zerrissenheit should be evident; but this is not the case. Indeed it is Rustan himself who first proposes that Zanga be dismissed once and for all from the peaceful cottage-world, a suggestion gladly welcomed by Massud, for he has witnessed just how susceptible Rustan's imagination has been to Zanga's negative influence. However, Massud does not fully detect what is stirring Rustan to countenance the quiet life, namely the latent anxiety that forces his weak nephew to repress the awareness that it is not his fate to be counted among the great figures of the world. Because ardent desire alone did not enable him to reach his overly-ambitious goal, Rustan now denies the existence of his passions. His attempt to straitjacket his unruly spirit into a life of calm will probably form the basis of a future neurosis rather than arousing harmonious feelings in Rustan.

Massud refuses to accept his nephew's professed psychological change at face value, nor does he give himself over to the benign vision of Rustan living in nuptial bliss with his daughter. Nevertheless, sufficient means whereby he might fathom the underlying reasons for Rustan's sudden psychological transformation are unavailable to the concerned father. Grillparzer points to the limitations of human reason in the Kantian sense. Massud gravely doubts the quality of Rustan's commitment to a life of self-imposed limitation. He knows him as being mentally incapable of finding inner peace. The sage's skepticism has been nurtured by the many negative experiences relating to his nephew's behaviour. By living in accord with Grillparzer's ethical ideal - "des Innern stiller Frieden und die schuldbefreite Brust" - Massud has discerned that any approximation of happiness 
is the byproduct of ethical action and a sense for honest being. Rustan, however, has neither the emotional inclination to live in modest contentment, nor does he possess the wisdom to comprehend that a guileless, peaceful life devoid of guilt is man's ultimate achievement. The viewpoints of the wise uncle and the wild nephew are incongruous because these men are radically different psychological types. To be content, one first must have a disposition that allows for contentment, yet a predilection for restrained and moral living has been missing in Rustan's psychic make-up from the outset of the play.

Mirza shares Massud's virtues, but her blinding love for Rustan becomes a fault that could lead to her ruin. Unlike her father, she impulsively places her trust in Rustan, as did Gülnare, and Gülnare was made to suffer unduly as a result. To say the least, Mirza's future is tenuous, for by heeding her heart she can be easily duped and made to experience tragedy through her marriage to Rustan, just like her upright dream-correspondent Gülnare. ${ }^{17}$ Rustan expresses precisely the sentiments that Mirza longs to hear, and so her faith in his sudden recovery places her into extreme danger. Mirza's emotions leave no room for rational clarity, and she brushes aside heartbreaking memories from the immediate past with her vision of future ecstasy. Rustan's brash manner in getting what he wants whenever he wants it is contagious. She ignores her reluctant father's caution by entreating him to give his immediate consent to their union in marriage; in effect, to submit at once to Rustan's irrational will.

Massud's initial monologue had characterized Rustan as irresponsible and unreliable (84 f.), and the dream has changed nothing. As the play draws to a close, Massud chafes at the pressure that the young couple bring to bear on him. Here again he reacts negatively to Rustan's wild and impulsive desires (26872694). He cautions his nephew to refrain from acting impetuously, yet Rustan, true to form, still refuses to bide his time:"Oheim, wie? und du kannst zweifeln? (2695). The concerned father's fear for his daughter's welfare notwithstanding, it is clear that Massud has adequate reasons to doubt Rustan's professed spiritual rebirth. He perceives how his daughter's emotions have made her easy prey to a Trugbild, her own unsafe illusion of a life of contentment through marriage to a good man. In her entreaty, "Höre ihn, Vater! Ist er doch so mild und gut!", the love-stricken daughter deplores the possibility that Rustan might not be relied upon by her father. Mirza's supplication, "Sprich ein Wort", is couched in lines of broken verse that fittingly reveal her hectic emotions (2702-2707). Yet Massud's last exclamation in the play in which he finally gives his consent is uttered

17. The negative and exploitative relationships that Grillparzer's male figures have with women are of special consequence. Just as Jason has no compunctions about using Medea's magic in order to attain the coveted golden fleece, and Ottokar's hubris prompts him to exploit every woman with whom he has contact, Rustan too takes advantage of the tender emotions of Mirza and Gülnare. 
softly. His words, "Ja, doch seis!", conclude the spoken drama, and along with the accompanying gesture in the penultimate action of the play dramatizing the father's feeble "Einwilligung" (SD /2722), his utterance contrasts markedly with the emotionally disordered language of Rustan and Mirza. Grillparzer's direction to have Massud speak "leise" testifies that the prudent man is still reluctant to accept Rustan's supposed cure as an accomplished fact. His consent here reflects his sense of impotence. It seems to signal that his chance to deal rationally with the disturbing question of what life with Rustan in their midst might bring has been throttled. To say "no" and thereby deny Mirza her naive expectation of happiness is to risk making his daughter forever resentful of him; to say "yes" is to consent to an impending struggle with Rustan's immoderate temperament, an irrational force opposed to peace and happiness, and one which the mild man can scarcely hope to vanquish. ${ }^{18}$ Even at this seemingly happy moment in Grillparzer's "dramatic fairy-tale", Massud finds it impossible to overcome the danger to reason and effective judgment. He senses that their spiritual peace, "des Innern stiller Frieden", is about to be put into unending jeopardy. Nevertheless, despite his trepidation about a future with his impetuous nephew, Massud acquiesces. He might feel that by consenting to the marriage, he chose the lesser of two evils in a gamble to make his daughter happy, yet Mirza's and Massud's dreamcorrespondents came to an unhappy end by relinquishing sound judgment to wishful-thinking. Instead of the protective guardian and saviour whom Gülnare and the Dream-King had hoped to find in Rustan, they discovered an egotistical scoundrel who wrought havoc in their lives. Rustan's indomitable will again reaches out for an object of its immediate desire, and in trying to protect his daughter, Massud finds himself virtually compelled into making a hasty decision.

Grillparzer was convinced that it was foolhardy to seek happiness through Ehrgeiz rather than self-knowledge. He therefore conveyed the message that unrealistic desires could only lead to broad social chaos. The father's apprehension has not been dispelled by appearances, and so the drama ends with the negativity of Rustan's "Worte", "Wünsche", "Taten", and with his unabating desire for instant gratification still holding sway over their positive counterparts. Will Massud in time manage to teach Rustan the positive values that are embodied in the song of the dervish? The open ending to Grillparzer's Der Traum ein Leben leaves a multiplicity of questions unanswered. Nevertheless, the final events on stage do not portend an auspicious beginning to Mirza's married life with the "New-Rustan". Although labeled a "dramatisches Märchen", the play does not

18. Politzer perceives Massud as already doubting whether his daughter's marriage to Rustan has any chance of survival, and "ob dieser rastlose Träumer es bei seiner allzu standfesten Tochter ein ganzes Leben lang wird aushalten können". Heinz Politzer, Franz Grillparzer oder Das abgründige Biedermeier. Wien-MünchenZürich 1972, p. 250. 
allow Rustan's destructive demon a shielding disguise, for it is clear that the "hero's" unchecked will-to-power is ready to gnaw away at the foundations of his latest illusion of happiness. However, despite such a disquieting view, Grillparzer's ethical insistence on mankind's need to shun counterfeit and corrupt ways of living imparts a Lebensweisheit; in this sense, the dramatic form that Grillparzer gives to his worldly wisdom replicates Friedrich Schiller's stage as a moral institution, albeit devoid of Schiller's heightened sense of optimism. Grillparzer's didactic intentions in Der Traum ein Leben are made to be taken seriously by his audience, even though the ramifications of Rustan's failure to understand and accept the play's moral imperative, "know thyself!", were obscured by the spectacular features of the moral Besserungsstück. Grillparzer's message to his compatriots to be wary of the façade-self could be tolerated as long as it remained unclear, whereas it was summarily rejected by the contemporary Viennese public when presented explicitly as a truth not to be disavowed. ${ }^{19}$

The condemnation of fraudulent dreams and dreamers highlights the playwright's belief in the futility of unrestrained self-assertion, yet Grillparzer's intentions have been falsely interpreted as including all forms of self-assertion. Indeed, his call for renunciation has melancholic overtones in as much as he was plagued by the pessimistic conviction that rational suggestions for living were unlikely to modify the behaviour of the Tatmensch. Yet even though Grillparzer condemns the blind ambition Rustan displays in Der Traum ein Leben, he was never opposed to advancement through moral means. Through the representation of psychologically destructive conflicts, Grillparzer endeavoured to warn and to

19. When the play was first performed in Vienna's Burgtheater on October 4, 1834 it proved to be successful for a time, which was not the case in other European capitals such as Prague and Berlin. The elements of the fantasy play and the fairytale enthralled the Viennese audience. However, it is doubtful whether Grillparzer's overriding concern with the issue of true values and his belief that happiness is a byproduct of genuine existence was ever correctly understood by his Viennese audience. With regard to this notion of "Schein" supplanting "Sein" in daily Viennese life, Henry Schnitzler's remarks on the enthusiastic reception of Der Traum ein Leben in 1834 are especially interesting. He says that "the play was a perfect expression not only of the traditional Baroque attitude but also of the atmosphere created by the Metternich period - flight from reality, life viewed as a shadow, a dream, as dangerous and chaotic, and as the result, inaction, resignation, escape. No wonder that the Viennese were highly pleased by what seemed to justify their philosophy of life". However, in commenting on Grillparzer's next play, Weh dem, der lügt!, Schnitzler contends that "the comedy Woe to Him Who Lies, in 1838, implied a different attitude. It is in brief, an allegory of the principle, Truth liberates. But who in Vienna wanted to be liberated by having to face a reality as unpleasant and exacting as the truth? The play was a failure." Henry Schnitzler, "Gay Vienna: Myth and Reality", Journal of the History of Ideas, 15 (1954) p. 108. 
enlighten, and therefore his work should not be seen as signaling a retreat from social responsibility. In the face of the ongoing social and psychological adversity confronting an intellectual in Metternich's Vienna, Grillparzer worked as a part of the enduring moral conscience of a Viennese society that progressively was being directed away from broad conceptions of justice and humanity as it moved toward private inwardness. By admonishing the potential man-of-action in Der Traum ein Leben to free himself of debilitating dreams, to check his volatile temperament, and to suppress his will-to-power, Grillparzer exhorts us all to avoid leading a life of duplicity. He suggests that only then might happiness be realized. Grillparzer thus dramatizes moral verities and necessities that are as significant for us today as they were in his own time. In the final analysis, if in Der Traum ein Leben the poet is heard tacitly disavowing the negative behaviour of ruthlessly ambitious men, he also lauds the unpretentious actions of ordinary people. True greatness is thus mirrored in the wholesome conduct of unselfish and unassuming individuals, which for Grillparzer was the essential source from which genuine happiness flowed. 